\title{
Development of mouse-specific contraceptive vaccines: infertility in mice immunized with peptide and polyepitope antigens
}

\author{
Christopher M Hardy, Gavin Clydesdale and Karen J Mobbs \\ Pest Animal Control Cooperative Research Centre, CSIRO Sustainable Ecosystems, GPO Box 284, Canberra, \\ ACT 2601, Australia
}

Correspondence should be addressed to C M Hardy; Email: chris.hardy@csiro.au

\begin{abstract}
Mouse-specific immunocontraceptive peptides have been identified in mouse proteins with key roles in reproduction from sequence comparisons to other species and tested for efficacy as immunocontraceptive antigens. Peptides were derived from granulocyte-macrophage colony-stimulating factor (GMCSF), the placental $27 \mathrm{kDa}$ heat-shock protein (HSP), leukemia inhibitory factor receptor (LIFR), oviduct glycoprotein (OGP), proliferin (PLF), prolactin (PRL), sperm protein SP56 and mouse zona pellucida subunits 1 and 3 (ZP1, ZP3). Fertility of female BALB/c mice was reduced after immunization with several peptides either conjugated to a carrier protein or in the form of recombinant polyepitopes. The most effective conjugated peptides (SP56, GMCSF and PRL) induced peptide-specific serum antibodies and reduced fertility by $\mathbf{5 0} \%$. Fertility of mice was also reduced after immunization with polyepitope antigens containing up to five different peptides fused to maltose-binding protein, but antibodies were not produced against all the encoded peptides. The most effective polyepitope antigen (containing PLF, SP56, ZP1 and ZP3 peptides) reduced fertility by $50 \%$ but induced only SP56 and ZP1 antibodies. We demonstrate that lack of antibody response to a given peptide epitope (ZP3) can be overcome if repeated copies are used in the polyepitope antigen construct, but the effect varies between mouse strains. We conclude that infertility induced in mice with a range of peptide-based vaccines is dependent on antigen formulation and genetic factors but does not necessarily correlate with peptide-specific antibody levels. In light of these results, strategies to improve the efficacy of peptide-based antifertility vaccines are discussed.
\end{abstract}

Reproduction (2004) 128 395-407

\section{Introduction}

Contraceptive vaccines are being developed to prevent fertility by triggering an autoimmune response to molecules essential for reproduction. Immunization against various proteins in sperm, testis, ovary, hormones and their receptor proteins has been successful at reducing fertility in a wide range of species (Delves et al. 2002, Ferro 2002). Some of the most effective antifertility vaccines currently under development use genetically modified viruses to deliver the reproductive antigens. Specifically, recombinant mouse-specific viruses, such as ectromelia virus (ECTV) and murine cytomegalovirus (MCMV), expressing the entire mouse egg protein ZP3 have been shown to cause long-term infertility in infected mice Jackson et al. 1998, Lloyd et al. 2003). The objective of this type of research is to produce transmissible vaccines that will spread in the field and cause sufficient infertility to reduce populations of the targeted animals to manageable levels (Tyndale-Biscoe 1994).
Contraceptive vaccines must be effective, long-lasting, cheap and readily applicable, and have no unacceptable side effects (Grandy \& Rutberg 2002). They may or may not need to be reversible depending on the application (Hoskinson et al. 1990, Aitken 2002). However, an additional but critical requirement for infertility vaccines intended for broad-scale uses, such as wildlife population control, is that they must be species-specific (Bradley et al. 1999). Lack of species-specificity of antifertility vaccines is widely documented for a range of reproductive antigens from sperm (Bandivdekar et al. 1991, Naz 2000), egg (Barber \& Fayrer-Hosken 2000) and hormones such as LHRH and human chorionic gonadotrophin (hCG) (Talwar 1997). Several groups have even identified universal contraceptive peptide antigens by immunologic or sequencebased comparisons of antigens derived from sperm (Zhu \& Naz 1994, O'Hern et al. 1995), egg (Hall et al. 1995, Zhu \& Naz 1999, Carino et al. 2002), hormones (Talwar 1997) and other proteins (Subramanian et al. 2003). Therefore, 
reliance on the species-specificity of the delivery vectors in the many vaccines under development raises the possibility that the fertility of non-target species could inadvertently be affected.

Immunization with proteins can have unexpected and undesirable side effects, including autoimmune diseases, particularly with self-antigens that have multiple functions or show considerable sequence homology to other proteins (Nettles 1997). To reduce the possibility of unwanted side effects and increase specificity, targeting of functional regions of the antigens is an attractive approach. Contraceptive peptide epitopes with reduced side effects (Lou et al. 1995, Sun et al. 1999) and increased species-specificity (Hinsch et al. 1999) have been described. These results show that peptide antigens can increase the species-specificity of antifertility vaccines, with the added benefit of reducing side effects.

The design of antifertility vaccines must address many of the same challenges facing the development of anticancer vaccines. Specifically, both types of vaccine should not affect normal tissues or their function, be able to overcome host down-regulation of autoreactive immune cells, and be efficacious in as many individuals as possible to reduce development of genetic resistance (Ferro 2002). In order to address these issues, anticancer vaccines under development use multiple peptides (Valmori et al. 2003) or polyepitope and multiple antigen peptides that contain strings of tumor-derived peptide epitopes and enhancers (Smith 1999, Suhrbier 2002). A similar need for multiple peptide antigens and immune enhancers in antifertility vaccines is demonstrated by the fact that individual peptides are often ineffective at inducing cross-reactive immunity to the native protein targets, perhaps for reasons such as conformational difference between the peptide and native protein or the inability of individuals to recognize certain epitopes due to major histocompatibility complex (MHC) restriction (Lou et al. 1995, Lea et al. 1998). In addition, polyepitope vaccines can potentially more closely mimic cases of documented natural autoimmunity where the physiological effect appears to require simultaneous immune responses against a number of different antigenic molecules (Bach et al. 1998).

The need for mouse-specific contraceptive antigens (Bradley et al. 1999), coupled with the availability of a wide range of reproductive proteins in the mouse genome database, makes this an ideal species in which to identify species-specific contraceptive peptides. Once promising peptides have been identified, they could potentially be used in combination with immune enhancers (Ramsay \& Ramshaw 1997) in the form of multivalent or polyepitope vaccines to generate stronger immune responses and more effective infertility. We have previously shown that the fertility of mice immunized with polyepitope antigens containing combinations of existing and novel mouse-specific peptides is significantly reduced (Hardy et al. 2002a).

Here, we report the relationship between infertility and the peptide-specific antibody responses in mice immunized with polyepitopes, and compare these to the responses in mice immunized with individual mousespecific peptides. On the basis of our results, we propose improvements in the design of species-specific polyepitope antigens that increase both immunogenicity and contraceptive effect.

\section{Materials and Methods \\ Mouse-specific peptides}

Mouse-specific peptides were derived from granulocytemacrophage colony-stimulating factor (GMCSF), the placental $27 \mathrm{kDa}$ heat-shock protein (HSP), leukemia inhibitory factor receptor (LIFR), oviduct glycoprotein $(\mathrm{OGP})$, proliferin (PLF), prolactin (PRL), sperm protein SP56 and mouse zona pellucida subunits 1 and 3 (ZP1, ZP3). The peptide sequences were selected from protein regions with relatively low homology between mouse and other species such as man (Table 1). Eight of the peptides (GMCSF, HSP, LIFR, OGP, PLF, PRL, SP56 and ZP3) were chemically synthesized by Mimotopes Pty Ltd (Clayton, Australia) with $\mathrm{N}$ - or C-terminal cysteine residues, naturally present in some of the peptides (GMCSF, PLF, SP56 and ZP3), to facilitate cross-linking to carrier molecules (Table 1). Peptide sequences and purity were determined by the manufacturers using reverse-phase HPLC. Due to the relatively large size of the ZP1 peptide (102 amino acids), it was produced and bounded by naturally occurring cysteine residues within a $6 \mathrm{XH}$ is fusion protein in Escherichia coli.

\section{Conjugation of peptides to $K L H$}

Peptides for immunization (Table 1) were conjugated to the carrier protein keyhole limpet hemocyanin (KLH) (Sigma) through the cysteine of the peptide by using $m$-maleimido benzoyl- $N$-hydroxysuccinimide ester (MBS) (Sigma) as the coupling reagent (Muller 1988). MBS $(10 \mathrm{mg} / \mathrm{ml}$ in dimethylformamide) was added dropwise to a solution of $\mathrm{KLH}\left(10 \mathrm{mg} / \mathrm{ml}\right.$ in $31 \mathrm{mM} \mathrm{Na}_{3} \mathrm{PO}_{4}, 460 \mathrm{mM}$ $\mathrm{NaCl}$ and $41 \mathrm{mM}$ sucrose) to give a final molar ratio of MBS to KLH of 40:1 (14 $\mu \mathrm{g} \mathrm{MBS} / \mathrm{mg} \mathrm{KLH})$. Unreacted MBS was removed by filtration through a Sephadex G$25 \mathrm{M}$ column (PD-10; Pharmacia Biotech, Uppsala, Sweden) equilibrated with $50 \mathrm{mM}$ phosphate buffer, $\mathrm{pH}$ 6.0. Activated KLH carrier protein was mixed with peptide $(2 \mathrm{mg} / \mathrm{ml})$ dissolved in PBS, $\mathrm{pH} 7.4$, to give a molar ratio of peptide:protein of 40:1 (0.2 mg peptide/mg KLH conjugate). The mixture was incubated for $3 \mathrm{~h}$ at room temperature with constant stirring and dialyzed against PBS overnight, and aliquots were stored at $-20^{\circ} \mathrm{C}$.

\section{Conjugation of peptides to BSA}

Two peptides (GMCSF and HSP) that failed in the immunologic assays when used directly were conjugated to bovine serum albumin (BSA) with glutaraldehyde (Muller 1988) for use in ELISA. Specifically, peptide was added 


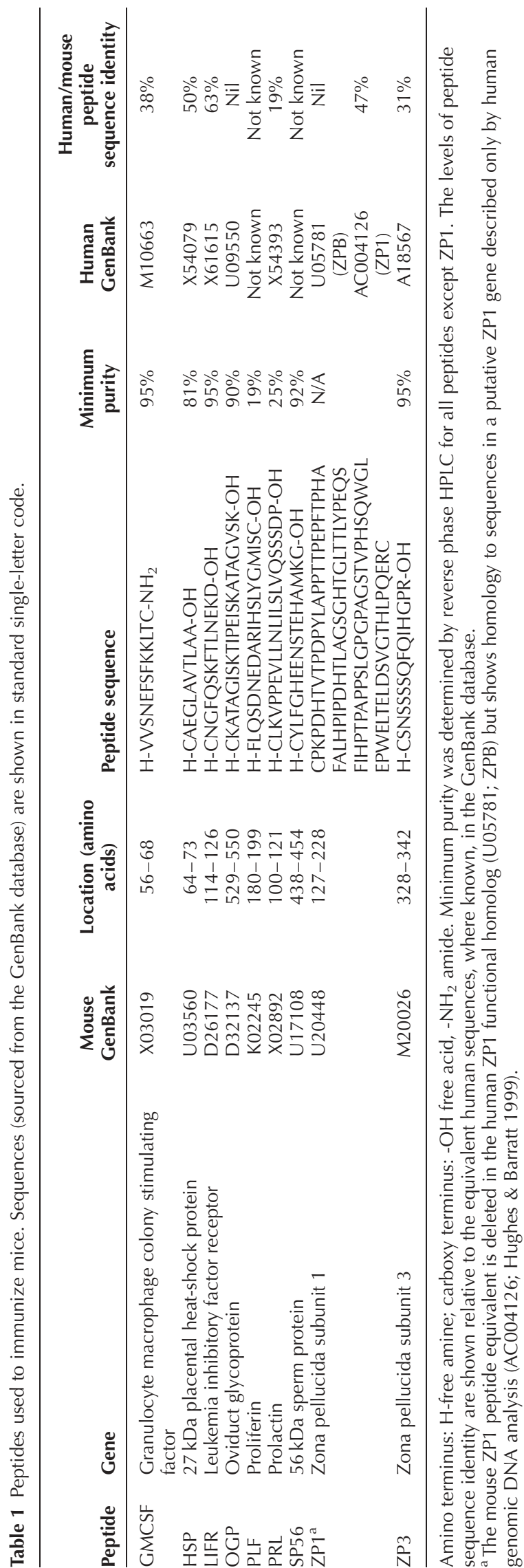

to BSA dissolved in PBS $(1 \mathrm{mg} / \mathrm{ml})$ at room temperature, to a final molar ratio of peptide to BSA of 40:1 (approximately $1 \mathrm{mg}$ peptide/mg BSA). The solution was cooled to $4{ }^{\circ} \mathrm{C}$, and an equal volume of glutaraldehyde in water $(2 \%$ $\mathrm{v} / \mathrm{v}$ ) was added, after which the solution was stirred at $4{ }^{\circ} \mathrm{C}$ for $1 \mathrm{~h}$. The glutaraldehyde was removed by dialysis against three changes of PBS, $\mathrm{pH} 7.4$, and aliquots of BSA-conjugated peptide were stored at $-20^{\circ} \mathrm{C}$.

\section{Assembly of polyepitope antigen DNA}

The DNA constructs for polyepitope antigen A (AgA, GenBank Accession No. AY521451; Fig 1A) and polyepitope antigen B (AgB, GenBank Accession No. AY521452; Fig 1B) were as described (Hardy et al. 2002a). Two foreign immunodominant $\mathrm{T}$ helper epitopes, BRN-T from bovine ribonuclease (Chen et al. 1991) and HA-T from influenza virus hemagglutinin (Sadler et al. 1999), were included in both polyepitopes to enhance immune responses to the mouse-specific peptides.

The DNA construct for the ZP1 peptide (nucleotides 436-741, GenBank Accession No. U20448) fused to 6XHis (Fig. 1C) was produced by first cloning a $312 \mathrm{bp}$ Spel/Sall fragment (nucleotides 355-660) from AgB (Hardy et al. 2002a) into the Xbal/Sall sites of pMALcRI (New England Biolabs, Beverly, MA, USA) to produce pMal:ZP1, followed by cloning a 377 bp Sacl/Hindlll fragment of pMAL:ZP1 into the Sacl/Hindlll sites of pQE31 (Qiagen) to produce pHis:ZP1.

The DNA construct for polyepitope antigen Z (AgZ, GenBank Accession No. AY521454; Fig. 1D) was assembled by sequential cloning of annealed oligomeric primers (Table 2) and PCR products. Specifically, a $372 \mathrm{bp}$ PCR fragment containing peptide sequences for mouse ZP3 and ZP1 was produced from AgB (Hardy et al. $2002 a$ ) with primers mZP3aF and mZP1aR. Next, the 33 bp annealed linkers ZP3F2 and ZP3R2, and ZP3F3 and ZP3R3 were sequentially inserted into the Spel site adjacent to the ZP3 sequence to produce AgZ (Fig. 1D). A 442 bp Xbal/EcolcRI fragment containing the AgZ was then inserted into pMALcR1 between the Xbal site and the HindIII site after it was end-filled, using Klenow enzyme, to produce pMal:AgZ. AgZ contains three tandem repeats of a ZP3 contraceptive B-cell epitope (FQIHGPR) (Millar et al. 1989) and a T-cell epitope (NSSSSQFQ) (Rhim et al. 1992) upstream of the ZP1 peptide sequence. Although this T-cell epitope has previously been implicated in causing oophoritis (ovarian inflammation) in some strains of mice (Lou et al. 1995), it was included in the polyepitope antigens as it is mouse-specific and its importance for the induction of infertility is unclear (Bagavant et al. 1999, Lou \& Borillo 2003). The synthetic primer sequences of the repeated ZP3 B-cell epitopes were modified relative to the published DNA sequence to prevent recombination between cloned sequences, but retain the same aminoacid translation. 
A

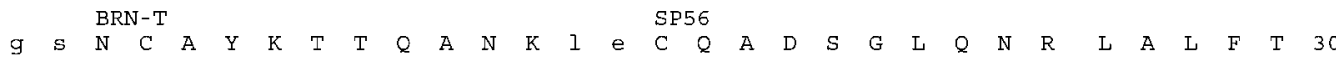
ggatcCAATTGTGCTTACAAGACGACACAGGCGAACAAActcgagTGTCAGGCAGACTCAGGCCTGCAAAACCGTCTTGCTCTTTTCACC 90

$\begin{array}{lllllllllllllllllllllllllllllllll}F & P & N & I & S & E & T & N & V & T & N & K & T & Y & \text { L } & F & G & H & E & E & \text { N } & S & \text { T } & \text { E } & \text { H } & \text { A } & \text { M } & K & \text { G } & \text { V } & 60\end{array}$ TTCCCAAACATATCAGAAACCAATGTGACAAACAAAACCTATCTATTTGGTCATGAAGAAAACTCAACCGAGCATGCCATGAAAGGTGTG 180 Proliferin HA-T

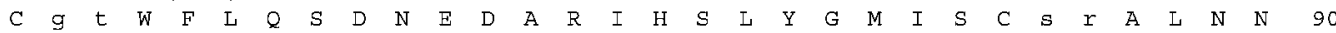
TGCggt acCTGGTTCITGCAATCTGACAATGAAGATGCTCGCATTCATTCITTITATATGGCATGATCAGCTGCtctagaGCGCTAAACAAC 270

$\begin{array}{lllllllllllllllllllllllllllllllllll}R & F & Q & I & K & G & V & E & L & K & S & Y & I & N & S & S & S & S & Q & F & Q & I & H & G & P & R & t & s & L & K & 120\end{array}$

$\begin{array}{llllllllllllllllllllllllllllllllll}R & F & Q & I & K & G & V & E & L & K & S & Y & I & N & S & S & S & S & Q & F & Q & I & H & G & P & R & t & S & L & K & 120\end{array}$ CGGTTTCAGATCAAAGGTGTTGAACTGAAAAGCaagct tAATTCAAGCTCTTCACAGTTCCAGATTCATGGACCCCGCactagtCTGAAA 360 Prolactin

$\begin{array}{lllllllllllllllllllllllllllllll}V & P & P & E & V & L & L & N & L & I & L & S & L & V & l & e & f & V & V & S & \text { N } & E & F & S & F & K & K & \text { I } & \text { T } & C & 150\end{array}$ GTCCCTCCGGAAGTTCTTCTGAACCTGATCCTCAGTTTGGTGctggaattcGTCGTCTCTAACGAGTTCTCCTTCAAGAAGCTAACATGT 450

$\mathrm{v} d$

gtcgac

152

B

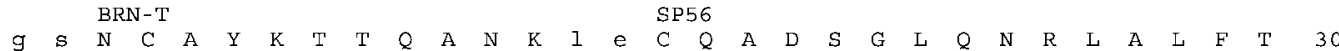
ggatCCAATTGTGCTTACAAGACGACACAGGCGAACAAACtCgagTGTCAGGCAGACTCAGGCCTGCAAAACCGTCTTGCTCTTTTCACC 90

$\begin{array}{lllllllllllllllllllllllllllllll}\text { F } & \text { P } & \text { N } & \text { I } & S & \text { E } & \text { T } & \text { N } & \text { V } & \text { T } & \text { N } & \text { K } & \text { T } & \text { Y } & \text { L } & \text { F } & \text { G } & \text { H } & \text { E } & \text { E } & \text { N } & \text { S } & \text { T } & \text { E } & \text { H } & \text { A } & \text { M } & \text { K } & G & V & 60\end{array}$ TTCCCAAACATATCAGAAACCAATGTGACAAACAAAACCTATCTATTTGGTCATGAAGAAAACTCAACCGAGCATGCCATGAAAGGTGTG 180

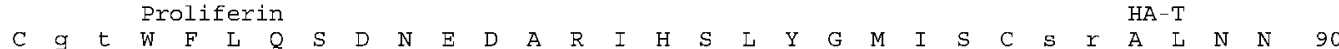

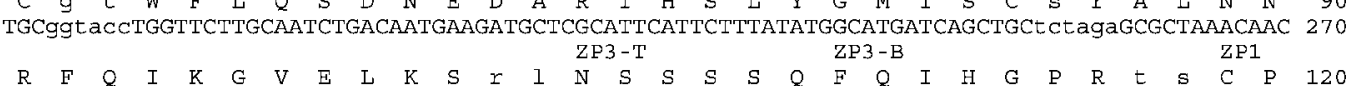
CGGTTTCAGATCAAAGGTGTTGAACTGAAAAGCaagct tAATTCAAGCTCTTCACAGTTCCAGATTCATGGACCCCGCactagtTGTCCC 360

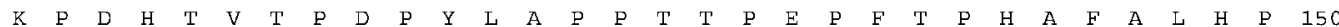
AAACCAGACCACACCGTGACTCCGGACCCCTACCTGGCTCCACCCACCACACCTGAGCCTTTTACACCTCATGCTTTTGCCCTTCACCCC 450

$\begin{array}{llllllllllllllllllllllllllllllll}\text { I } & \mathrm{P} & \mathrm{D} & \mathrm{H} & \mathrm{T} & \mathrm{L} & \mathrm{A} & \mathrm{G} & \mathrm{S} & \mathrm{G} & \mathrm{H} & \mathrm{T} & \mathrm{G} & \mathrm{L} & \mathrm{T} & \mathrm{T} & \mathrm{L} & \mathrm{Y} & \mathrm{P} & \mathrm{E} & \mathrm{Q} & \mathrm{S} & \mathrm{F} & \mathrm{I} & \mathrm{H} & \mathrm{P} & \mathrm{T} & \mathrm{P} & \mathrm{A} & \mathrm{P} & 180\end{array}$ ATCCCTGACCACACCITGGCTGGGTCTGGCCACACTGGTCTCACTACGTTGTACCCAGAACAGAGCITCATCCATCCAACTCCTGCTCCG 540

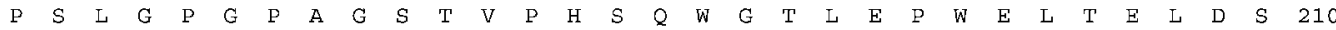
CCATCCCTAGGACCTGGACCTGCTGGATCCACTGTACCTCACTCCCAATGGGGACGCTGGAGCCCTGGGAATTGACTGAGCTGGATTCT 630

$\begin{array}{llllllllllllllll}V & G & T & H & L & P & Q & E & R & C & V & d\end{array}$

222

GTAGGTACCCATCTGCCCCAGGAGCGGTGCgtcgac

666

C

m r g s $\begin{aligned} & \text { 6XHis } \\ & \text { m h }\end{aligned}$ atgagaggatcgcatcaccatcaccatcacacggatccgcatgcgagctcggtaccgtcctctctcgtgatcgagggaaggatttcagaa 90

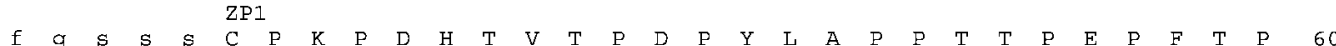
ttcggatcctctagt TGTCCCAAACCAGACCACACCGTGACTCCGGACCCCTACCTGGCTCCACCCACCACACCTGAGCCTTTTACACCT 180

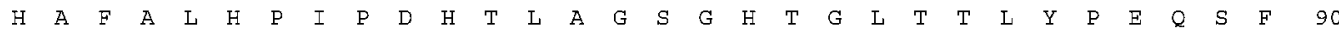
CATGCTTTTGCCCTTCACCCCATCCCTGACCACACCTTGGCTGGGTCTGGCCACACTGGTCTCACTACGTTGTACCCAGAACAGAGCTTC 270

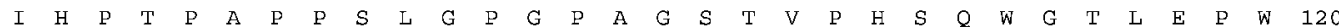
ATCCATCCAACTCCTGCTCCGCCATCCCTAGGACCTGGACCTGCTGGATCCACTGTACCTCACTCCCAATGGGGCACGCTGGAGCCCTGG 360

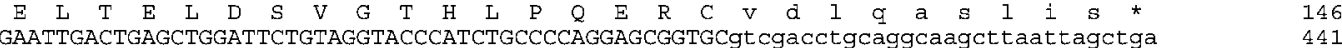

D

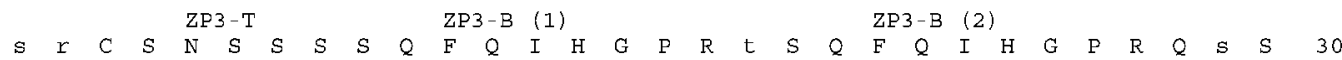
tctagaTGTTCTAATTCAAGCTCTTCACAGTTCCAGATTCATGGACCCCGCactAGTCAATTCCAAATTCACGGGCCGAGGCAAtctAGT 90 ZP3-B (3)

$\begin{array}{lllllllllllllllllllllllllllllllll}Q & F & Q & I & H & G & P & R & Q & S & S & C & P & K & P & D & H & T & V & T & P & D & P & Y & \text { L } & A & P & P & T & T & 60\end{array}$ CAATTTCAAATCCACGGTCCTAGACAAt ctagtTGTCCCAAACCAGACCACACCGTGACTCCGGACCCCTACCTGGCTCCACCCACCACA 180

$\begin{array}{llllllllllllllllllllllllllllllllll}P & E & P & F & T & P & H & A & F & A & \text { L } & \text { H } & \text { P } & \text { I } & \text { P } & \text { D } & \text { H } & \text { T } & \text { L } & \text { A } & \text { G } & S & G & \text { H } & \text { T } & G & \text { L } & \text { T } & \text { T } & \text { L } & 90\end{array}$ CCTGAGCCTTTTACACCTCATGCTTTTGCCCTTCACCCCATCCCTGACCACACCTTGGCTGGGTCTGGCCACACTGGTCTCACTACGTTG 270

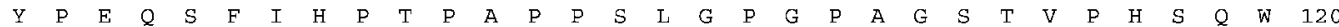
TACCCAGAACAGAGCTTCATCCATCCAACTCCTGCTCCGCCATCCCTAGGACCTGGACCTGCTGGATCCACTGTACCTCACTCCCAATGG 360

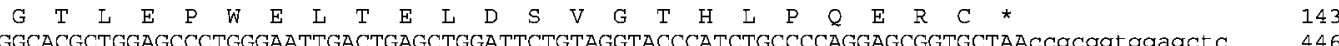

Figure 1 Nucleotide and deduced amino-acid sequences for polyepitope AgA (A), polyepitope AgB (B), ZP1 peptide fused to a 6XHis tag (C) and polyepitope AgZ (D). The locations of peptide sequences are shown above the sequences. The nucleotide and amino-acid sequences corresponding to the peptide sequences are shown in uppercase. The nucleotide and amino-acid sequences of the restriction sites introduced between the peptides during cloning steps and for bacterial expression are shown in lowercase. 
Table 2 Oligonucleotides used to produce polyepitope AgZ. Nucleotide locations are relative to the sequence for AgZ (GenBank Accession No. AY521454).

\begin{tabular}{llr}
\hline Oligonucleotide & Sequence $\left.\mathbf{( 5}^{\prime}-\mathbf{3}^{\prime}\right)$ & Location \\
\hline mZP3aF & TCTAGATGTTCTAATTCAAGCTCTTCAC & $1-28$ \\
mZP1aR & CCGCGGTTAGCACCGCTCCTGGGGC & $438-414$ \\
ZP3F2 & CTAGTCAATTCAAATCCACGGTCCTAGACAAT & $86-118$ \\
ZP3R2 & CTAGATTGTCTAGGACCGTGGATTGAAATTGA & $122-90$ \\
ZP3F3 & CTAGTCAATTCCAAATTCACGGGCCGAGGCAAT & $53-85$ \\
ZP3R3 & CTAGATTGCCTCGGCCCGTGAATTTGGAATTGA & $89-57$ \\
\hline
\end{tabular}

\section{Protein purification}

Recombinant 6XHis fused ZP1 peptide was prepared and affinity purified with Ni-NTA Superflow resin (Qiagen) in $6 \mathrm{M}$ urea and renatured by sequential dialysis according to the manufacturer's recommendations. Recombinant AgZ fused to MBP was prepared and affinity purified with amylose resin as previously described (Hardy \& Holland 1996). All recombinant protein expression was conducted with E. coli strain BL21 CodonPlus-RIL (Stratagene, La Jolla, CA, USA). Polyacryamide gel electrophoresis was conducted by standard procedures (Coligan et al. 1995), with low-range prestained proteins (BioRad, Hercules, CA, USA) as molecular weight markers. Molecular weight predictions were conducted with the Swiss-Prot analysis tool (Boeckmann et al. 2003) on the ExPASy server (Gasteiger et al. 2003).

\section{Immunization and mating protocols}

The Animal Experimentation and Ethics Committee of the Commonwealth Scientific and Industrial Research Organization, Division of Sustainable Ecosystems, approved all experimental procedures involving the use of mice, in compliance with the Australian National Health and Medical Research Council guidelines.

$\mathrm{BALB} / \mathrm{C}$ mice (6-8 weeks old) were obtained from the Animal Resources Centre, Murdoch, Perth, Australia. CBA mice (6-8 weeks old) were obtained from the Australian National University Animal Resources Centre, Canberra, Australia. Female mice were immunized by intraperitoneal (i.p.) injection with $20 \mu \mathrm{g}$ peptide conjugate or recombinant protein in $100 \mu \mathrm{l} 50 \%$ PBS and 50\% Freund's complete adjuvant (FCA) (Sigma), and boosted by i.p. injection three or four times with $20 \mu \mathrm{g}$ peptide conjugate in $100 \mu \mathrm{l} 50 \%$ PBS and 50\% Freund's incomplete adjuvant (FIA) (Sigma) at 2-week intervals. Blood samples were collected before each boost and 2 weeks after the final boost from the suborbital sinus. The blood was then spun at 1500 r.p.m. for $5 \mathrm{~min}$, and the sera were collected and stored at $-20^{\circ} \mathrm{C}$ until tested.

Female BALB/c mice were coupled 2 weeks after the final immunization with proven fertile BALB/c males of similar age. Males were removed after 2 weeks and the females allowed to litter. Female CBA mice were coupled 2 weeks after the final immunization with CBA males, and the males were removed after 2 weeks and the females allowed to litter. Fresh males were then introduced to any female CBA mice that failed to litter ( 5 weeks after the final immunization) for a further 2 weeks, and the females again allowed to litter. After littering was completed, pups were killed and the females were autopsied.

\section{Histology}

Female mice were killed by cervical dislocation and the ovaries were collected and fixed in Bouin's fixative (71.4\% saturated picric acid, 9.5\% formaldehyde and $4.8 \%$ glacial acetic acid). Bouin's fixative was replaced by $70 \%$ ethanol before tissues were embedded in paraffin wax. Tissue sections $(7 \mu \mathrm{m})$ were stained with hematoxylin and eosin.

\section{Assay of antibodies}

Serum IgG antibody levels were determined by enzymelinked immunosorbent assay (ELISA) in 96-well microtiter plates (Greiner, Labortechnik GmbH, Frickenhausen, Germany, or Nalge Nunc, Rochester, NY, USA). Sera from mice recognized unconjugated peptides for all peptides except GMCSF and HSP when they were used as detection antigens in ELISA. Peptides GMCSF and HSP were therefore conjugated to BSA to improve detection. Unconjugated peptides or peptides conjugated to BSA were suspended in binding buffer $(50 \mathrm{mM} \mathrm{NaHCO} 3 \mathrm{pH}$ 9.6) and added to microtiter plates $(1.0 \mu \mathrm{g}$ antigen in $50 \mu \mathrm{l} / \mathrm{well})$ and incubated for either $1 \mathrm{~h}$ at $37^{\circ} \mathrm{C}$ or overnight at $4{ }^{\circ} \mathrm{C}$. After the incubation, wells were washed three times with ELISA buffer $\left(145 \mathrm{mM} \mathrm{NaCl}, 7.5 \mathrm{mM} \mathrm{Na}_{2} \mathrm{HPO}_{4}\right.$ and $2.5 \mathrm{mM} \mathrm{NaH} \mathrm{PO}_{4}$, containing $0.005 \%$ Tween-20, pH 7.4). Nonspecific binding was prevented by incubation in ELISA buffer containing $5 \%(\mathrm{w} / \mathrm{v})$ skim-milk powder for $1 \mathrm{~h}$ at $37^{\circ} \mathrm{C}$. Plates were washed three times with ELISA buffer, and $50 \mu \mathrm{l}$ serum samples diluted in ELISA buffer containing $1 \%(\mathrm{w} / \mathrm{v})$ skim-milk powder were added to wells in duplicate, and incubated for $1 \mathrm{~h}$ at $37^{\circ} \mathrm{C}$. Wells were washed three times with ELISA buffer, and $50 \mu \mathrm{l}$ affinity-purified and horseradish peroxidase-labeled goat antimouse IgG (Silenus Laboratories, Hawthorn, Australia) diluted 1:3000 in ELISA buffer containing 1\% (w/v) skimmilk powder was added to each well. After a further incubation of $1 \mathrm{~h}$ at $37^{\circ} \mathrm{C}$, plates were washed with ELISA buffer and color developed by adding $50 \mu \mathrm{l}$ development buffer. Development buffer consisted of $0.01 \% \mathrm{H}_{2} \mathrm{O}_{2}$, 


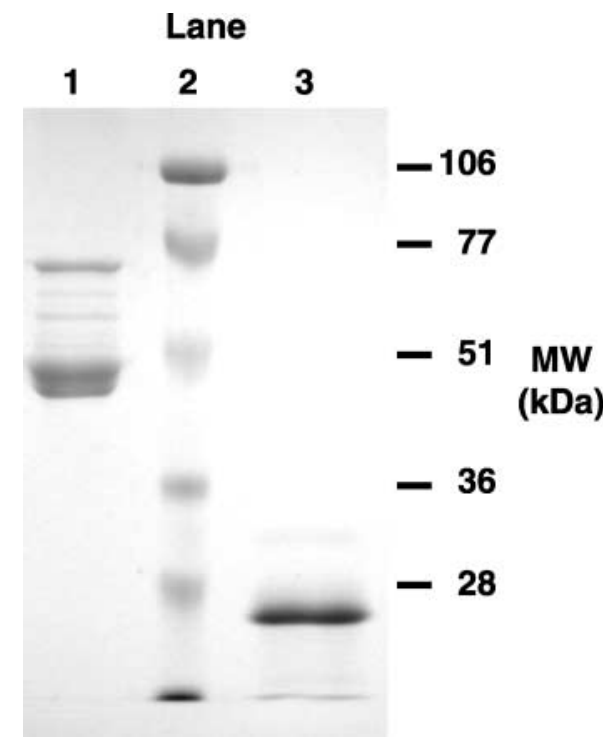

Figure 2 SDS-PAGE gel stained with Coomassie brilliant blue showing purified recombinant peptide antigens. Lane 1, polyepitope AgZ fused to maltose-binding protein; lane 3, ZP1 peptide fused to 6XHis tag; lane 2, molecular mass markers.

2 mM ABTS (2,2'-azino-bis(3-ethylbenzothiazoline-6-sulfonic acid) diammonium salt (Sigma), in acetate buffer ( $100 \mathrm{mM}$ sodium acetate and $50 \mathrm{mM} \mathrm{NaH} \mathrm{PO}_{4}, \mathrm{pH} 4.0$ ) and was prepared immediately prior to use. Reactions were terminated after $20 \mathrm{~min}$ at $20^{\circ} \mathrm{C}$ by addition of $50 \mu \mathrm{l}$ $10 \%$ SDS, and absorbance was measured at $405 \mathrm{~nm}$ on an ELISA plate reader (Bio-Rad). Means of duplicate samples are reported.

\section{Statistical analyses}

Results are presented as means \pm S.E.M. Data were analyzed by two-tailed Student's $t$-test (GenStat for Windows 2002, 6th edn, VSN International Ltd, Hemel Hempstead, UK). A value of $P<0.05$ was considered significant.

\section{Results \\ Purification of recombinant proteins}

The predicted sizes and molecular masses MBP:AgZ and 6XHis:ZP1 were 530 amino acids and $58 \mathrm{kDa}$, and 146 amino acids and $16 \mathrm{kDa}$ respectively. The purified 6XHis:ZP1 peptide appeared as a single $20 \mathrm{kDa}$ band on SDS-PAGE gels (Fig. 2, lane 3), slightly higher than the predicted molecular mass of $16 \mathrm{kDa}$ for the 146 -aminoacid product. The purified MBP:AgZ appeared as two main products of 48 and $50 \mathrm{kDa}$, slightly lower than the predicted molecular mass of $58 \mathrm{kDa}$ for the 530 -aminoacid fusion protein (Fig. 2, lane 1). A minor, higher molecular weight product of $70 \mathrm{kDa}$ was also present in the MBP:AgZ preparation.

\section{Fertility of mice immunized with peptide antigens}

The most effective peptides for reducing fertility in mice were SP56, GMCSF and PRL, and only $40 \%$ of mice in each of these groups produced litters compared with PBS controls where $80 \%$ of mice were fertile (Table 3). The use of these three peptides in combination also reduced

Table 3 Fertility of mice immunized with different peptide antigen formulations. Female BALB/c or CBA mice were immunized and boosted 3-4 times at 2-week intervals with antigen in Freund's adjuvants. Individual or groups of peptides were either keyhole limpet hemocyanin (KLH) conjugates or fused to a 6 XHis tag (peptide ZP1). Recombinant polyepitopes (AgA, AgB and AgZ) were fused to maltose-binding protein (MBP). $\mathrm{BALB} / \mathrm{c}$ mice were mated 2 weeks after the final boost. CBA mice were mated 2 and 5 weeks after the final boost. Significant differences $(P<0.05)$ from controls (PBS or KLH) are shown in bold type.

\begin{tabular}{|c|c|c|c|c|c|c|c|c|}
\hline $\begin{array}{l}\text { Mouse } \\
\text { strain }\end{array}$ & Peptide antigen & Total mice & Total boosts & Fertile mice & Fertility (\%) & Total pups & $\begin{array}{l}\text { Litter size of fertile mice } \\
\quad(\text { mean } \pm \text { S.E.M. })\end{array}$ & $P^{\mathrm{a}}$ \\
\hline \multirow[t]{16}{*}{$\mathrm{BALB} / \mathrm{C}$} & SP56 & 5 & 3 & 2 & 40 & 6 & $3.0 \pm 1.3$ & 0.03 \\
\hline & GMCSF & 5 & 3 & 2 & 40 & 7 & $3.5 \pm 1.4$ & 0.05 \\
\hline & PRL & 5 & 3 & 2 & 40 & 12 & $6.0 \pm 1.7$ & 0.60 \\
\hline & SP56 + GMCSF + PRL & 6 & 3 & 3 & 50 & 16 & $5.3 \pm 1.1$ & 0.22 \\
\hline & LIFR & 5 & 3 & 3 & 60 & 13 & $4.3 \pm 1.2$ & 0.09 \\
\hline & PLF & 5 & 3 & 3 & 60 & 17 & $5.7 \pm 1.1$ & 0.34 \\
\hline & HSP & 5 & 3 & 4 & 80 & 20 & $5.0 \pm 1.0$ & 0.13 \\
\hline & OGP & 5 & 4 & 5 & 100 & 32 & $6.4 \pm 0.8$ & 0.55 \\
\hline & ZP1 & 10 & 3 & 9 & 90 & 47 & $5.2 \pm 0.7$ & 0.08 \\
\hline & $\mathrm{AgA}^{\mathrm{b}}$ & 10 & 3 & 6 & 60 & 33 & $5.5 \pm 0.9$ & 0.24 \\
\hline & $\mathrm{AgB}^{\mathrm{b}}$ & 10 & 3 & 4 & 40 & 21 & $5.3 \pm 1.1$ & 0.23 \\
\hline & AgZ & 9 & 3 & 7 & 78 & 24 & $3.4 \pm 0.9$ & 0.01 \\
\hline & $\mathrm{MBP}^{\mathrm{b}}$ & 10 & 3 & 7 & 70 & 52 & $7.4 \pm 0.8$ & 0.71 \\
\hline & PBS & 10 & 3 & 8 & 80 & 56 & $7.0 \pm 0.8$ & \\
\hline & $\mathrm{ZP}^{\mathrm{c}}$ & 10 & 4 & 9 & 90 & 32 & $3.6 \pm 0.6$ & 0.07 \\
\hline & $\mathrm{KLH}^{\mathrm{c}}$ & 14 & 4 & 11 & 79 & 55 & $5.0 \pm 0.5$ & \\
\hline \multirow[t]{2}{*}{ CBA } & $\mathrm{AgZ}$ & 6 & 3 & 3 & 50 & 16 & $5.3 \pm 1.1$ & 0.93 \\
\hline & PBS & 6 & 3 & 5 & 83 & 26 & $5.2 \pm 0.9$ & \\
\hline
\end{tabular}

a Probability that the experimental treatment was significantly less than control values.

${ }^{\mathrm{b}}$ Data from Hardy et al. (2002a).

${ }^{\mathrm{c}}$ Data from Hardy et al. (2002b). 
fertility in mice, but was slightly less effective $50 \%$ of mice produced litters) than when peptides were used individually. Mice immunized with two of the peptides (SP56 and GMCSF) chemically coupled to KLH produced significantly fewer pups than controls $(P=0.03$ and 0.05 respectively), indicating that the effect of these two peptides was to cause a reduction in the mean litter sizes of mice (Table 3). Peptides LIFR and PLF also appeared to reduce fertility, although to a lesser extent $(60 \%$ of mice produced litters). The remaining peptides (HSP, OGP and ZP3 conjugated to $\mathrm{KLH}$, or ZP1 fused to a $6 \mathrm{XH}$ is tag) did not significantly affect the fertility of female BALB/c mice.

\section{Fertility of mice immunized with polyepitope antigens}

Fertility of BALB/c mice immunized with $\mathrm{AgA}(60 \%)$ and $\mathrm{AgB}(40 \%)$ has been previously reported (Hardy et al. 2002a). Fertility of mice immunized with AgZ (78\%) was similar to the control groups immunized with PBS $(80 \%)$ or MBP $(70 \%)$. Although most BALB/c mice produced litters after immunization with $\mathrm{AgZ}$, there was a highly significant reduction $(P=0.01)$ in the mean litter sizes of the mice that produced litters compared with PBS-treated controls (Table 3).

In a separate experiment, we assessed the fertility of CBA mice immunized with MBP:AgZ under identical conditions to BALB/c mice. However, in this experiment, the CBA mice had generally low fertility and delayed breeding compared with the BALB/c mice. After the mice were first mated 2 weeks after the final boost, only 2/6 AgZ-treated and 2/6 PBS-treated mice had produced litters. One further AgZ and three PBS-treated mice produced litters when fresh males were introduced 5 weeks after the final boost to the mice that failed to litter in the first mating. Overall, by 8 weeks after the final boost, the proportion of CBA mice that produced litters after immunization with AgZ (50\%) was less than PBS controls (83\%), although no significant difference in mean litter sizes was present between the fertile mice in the two groups (Table 3).

\section{Antibody responses in mice immunized with peptide antigens}

Most female BALB/c mice immunized by repeated i.p. injection with conjugated peptides produced detectable peptide-specific IgG antibodies by 2 weeks after the second boost (Fig. 3), and these subsequently increased in many but not all mice after a further boost.

Mice immunized with individual peptides developed consistently strong antibody responses against LIFR, ZP1 and ZP3. In contrast, peptide-specific IgG antibodies against the remaining peptides were either highly variable (GMCSF, PLF, PRL, OGP and SP56) between individual mice or absent (HSP). In particular, significant IgG responses (absorbance of $>0.1$ at 1:100 serum dilution) were produced after immunization in only a fraction of individuals for peptides PLF (2/5 responders) and $\operatorname{OGP}(2 / 5)$.
Mice immunized with a combination of three peptides (SP56, GMCSF and PRL) had similar response profiles to each peptide as mice immunized with the single peptides. However, individual mice immunized with single peptides developed considerably higher peptide specific antibodies than mice immunized with the same peptide in combination with others, with levels up to 2-fold higher for GMCSF and PRL and as much as 10-fold higher for SP56 (Fig. 3).

\section{Antibody responses in mice immunized with polyepitope antigens}

Previously, mice immunized with $\mathrm{AgA}$ and $\mathrm{AgB}$ were shown to produce strong antibody responses to the polyepitopes, but the response to the component peptides was not assessed (Hardy et al. 2002a). Sera from these mice collected 2 weeks after the final boost were therefore tested for the presence of peptide-specific antibodies, and only certain peptides were recognized in ELISA. All 10 mice immunized with AgA (containing GMCSF, PLF, PRL, SP56 and ZP3 peptide sequences) produced SP56-specific antibodies, two had traces of ZP3 antibodies (absorbance $=0.13,0.16)$ and none developed GMCSF, PLF or PRL-specific antibodies (Fig. 4). All 10 mice immunized with AgB (containing PLF, SP56, ZP1 and ZP3 peptide sequences) produced SP56-specific and ZP1-specific antibodies (Fig. 4), but failed to produce antibodies against PLF or ZP3.

The absence of significant ZP3 antibody responses in mice immunized with $\mathrm{AgA}$ and $\mathrm{AgB}$ led us to produce a third polyepitope (AgZ). This contained the immunodominant peptide from AgB (ZP1) and three tandem repeats of the ZP3 peptide containing a known contraceptive B-cell epitope (Fig. 1D). This was to test whether the tandem repeats were able to enhance the production of ZP3specific antibodies while not affecting responses to ZP1. All 10 female BALB/C mice immunized with AgZ produced both ZP1 and ZP3 antibodies (Fig. 4) at levels comparable to mice immunized with the individual peptides. The ability to induce ZP3 antibodies in the mice, however, is dependent on the mouse strain. CBA mice, reportedly resistant to the immunocontraceptive effects of ZP3 antigens (Lloyd et al. 2003), were immunized with AgZ under identical conditions to BALB/C mice but generated antibody responses to only the ZP1 peptide (Fig. 4).

\section{Relationship between antibody responses and fertility in mice immunized with peptide and polyepitope antigens}

The relative levels of peptide-specific antibody responses of fertile and infertile mice immunized with conjugated peptides were compared with those induced by the same sequences delivered as recombinant polyepitopes. The final antibody response to any given peptide by individual mice was not indicative of whether the animals were subsequently found to be infertile (Figs 3 and 4). 

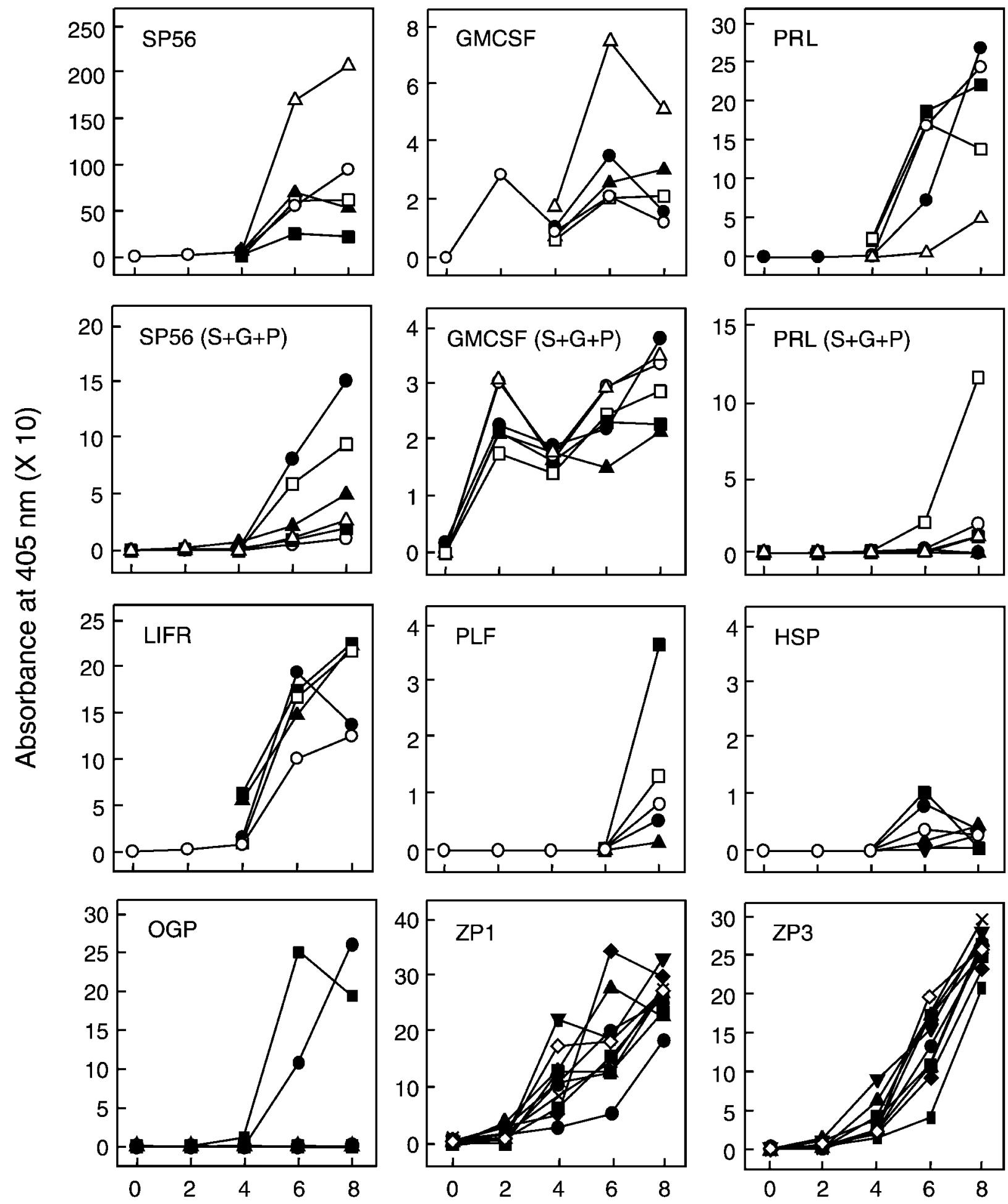

\section{Weeks post immunization}

Figure 3 Progression of serum IgG antibody responses by ELISA in female BALB/c mice immunized and boosted three times at 2-week intervals with peptides in Freund's adjuvants. Individual or groups of peptides were either keyhole limpet hemocyanin (KLH) conjugates or fused to a 6XHis tag (peptide ZP1). SP56 (S + G + P), GMCSF (S + G + P) and PRL (S + G + P) indicate response to SP56, GMCSF and PRL respectively from mice immunized with mixed peptides SP56, GMCSF and PRL. Absorbance values are shown for sera diluted 1:100 (SP56 was diluted 1:1000). Open symbols show individual mice that were subsequently infertile upon mating at 8-10 weeks. 


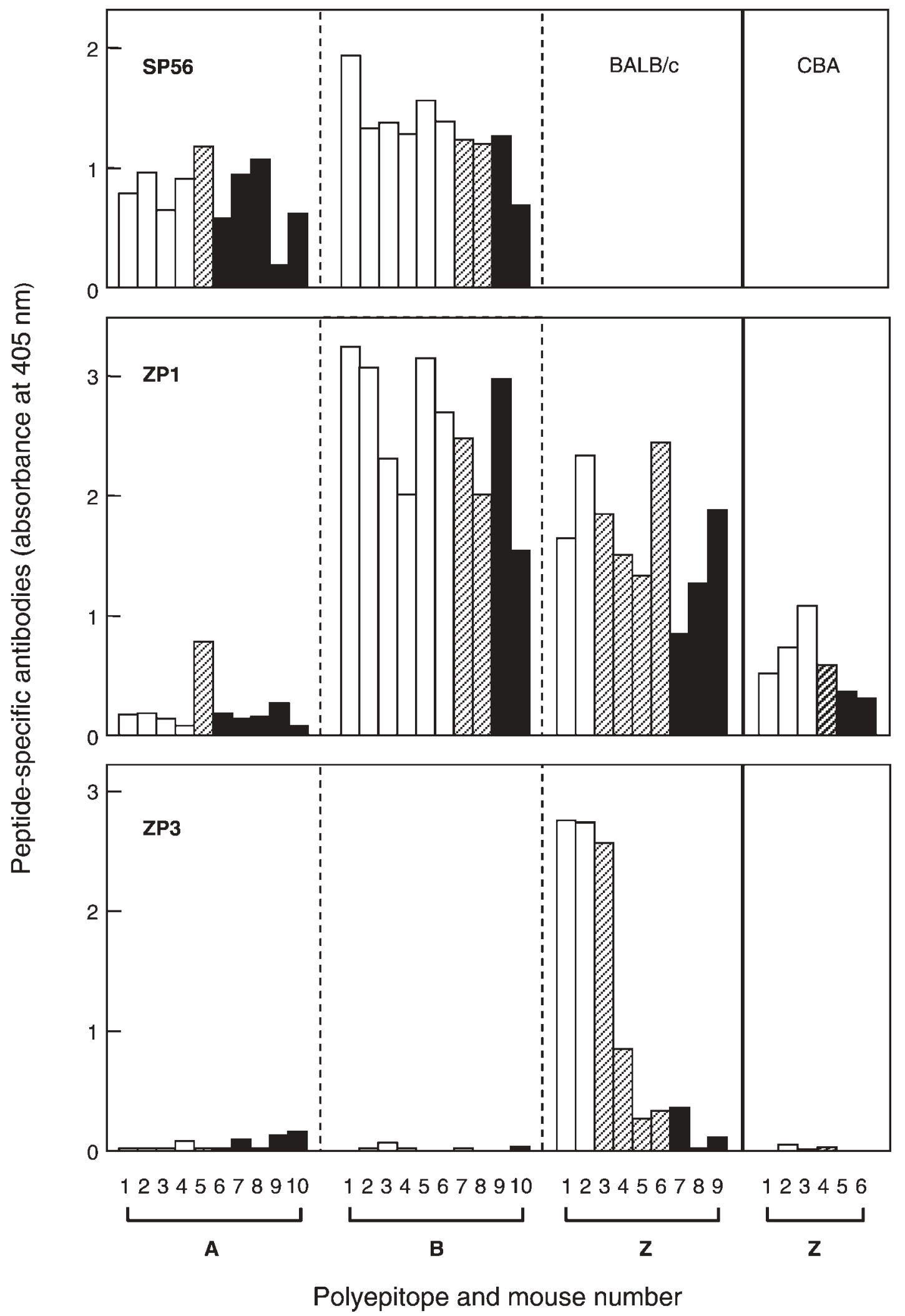

Figure 4 Peptide-specific serum IgG antibody responses in mice immunized with recombinant polyepitope antigens. Female BALB/c or CBA mice were immunized in Freund's adjuvants and boosted three times at 2-week intervals with AgA, AgB or AgZ fused to maltose-binding protein. Values are mean \pm S.E.M. absorbance values at $405 \mathrm{~nm}$ (1:100 serum dilutions) by ELISA against the peptides for each mouse, 2 weeks after the final immunization. Open bars indicate infertile mice; hatched bars indicate mice with $1-3$ pups; solid bars indicate mice with more than three pups. 
Nevertheless, significant differences were present between the levels of peptide-specific antibodies produced by fertile and infertile mice immunized with two of the antigen formulations. Specifically, peptide-specific antibody levels were significantly higher for peptide SP56 in infertile compared with fertile BALB/c mice immunized with $\mathrm{AgB}$ (absorbance $=1.5 \pm 0.1$ vs $1.1 \pm 0.1$ respectively; $P=0.05$ ) and for peptide ZP3 in infertile compared with fertile $\mathrm{BALB} / \mathrm{c}$ mice immunized with AgZ (absorbance $=$ $2.7 \pm 0.6$ vs $0.6 \pm 0.3$ respectively; $P=0.015$ ).

\section{Ovarian effects in mice treated with polyepitope antigen $Z$}

Ovaries of $\mathrm{CBA}$ and BALB/c mice immunized with AgZ and ZP1 were examined for evidence of ovarian pathology 8 weeks after the final immunization, once production of litters had been completed (Fig. 5). Ovaries from all mice immunized with PBS contained primary, preantral and antral follicles, and corpora lutea were also present in mice that produced litters (Fig. 5A and B). Likewise, ovaries from all BALB/c mice and fertile CBA mice immunized with AgZ (Fig. 5C) contained primary, preantral and antral follicles as well as corpora lutea. However, ovaries from infertile CBA mice immunized with AgZ were abnormal, lacked antral follicles and contained very few primary or preantral follicles (Fig. 5D). Ovaries from all 6XHis:ZP1-treated BALB/c mice, including the single infertile animal, appeared normal and contained all stages of follicles and corpora lutea (Fig. 5E and F).

\section{Discussion}

We have demonstrated that fertility of mice is significantly reduced by up to $50 \%$ after immunization with peptide and polyepitope antigens that target a range of proteins involved in reproduction. All peptides were selected on the basis of low amino-acid sequence identity to the corresponding sequences from homologous proteins in other species and are therefore considered to represent potential mouse-specific contraceptive antigens. Peptides were produced by two independent methods: either chemically synthesized and conjugated to a carrier protein or expressed in bacteria as recombinant polyepitopes.

Mice were immunized with conjugated peptides using protocols that have previously been shown to induce both strong peptide-specific antibody responses and infertility (Millar et al. 1989, Sun et al. 1999, Hardy et al. 2002b). Most mice developed peptide-specific antibodies in

\section{Fertile}
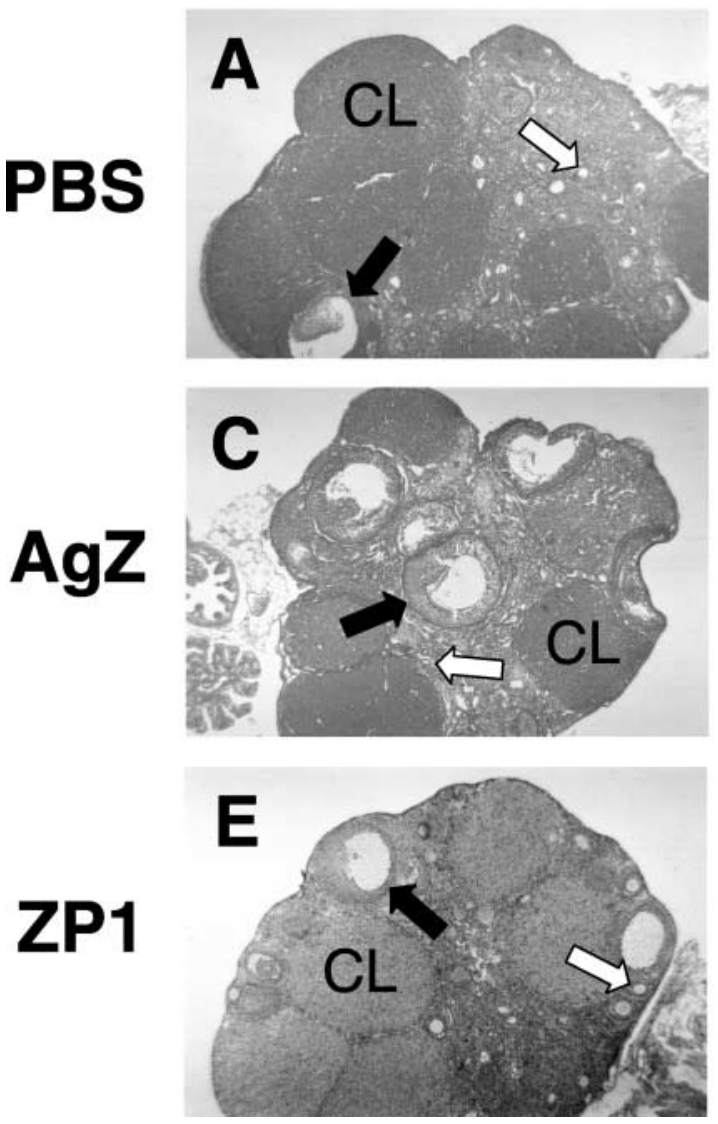

\section{Infertile}
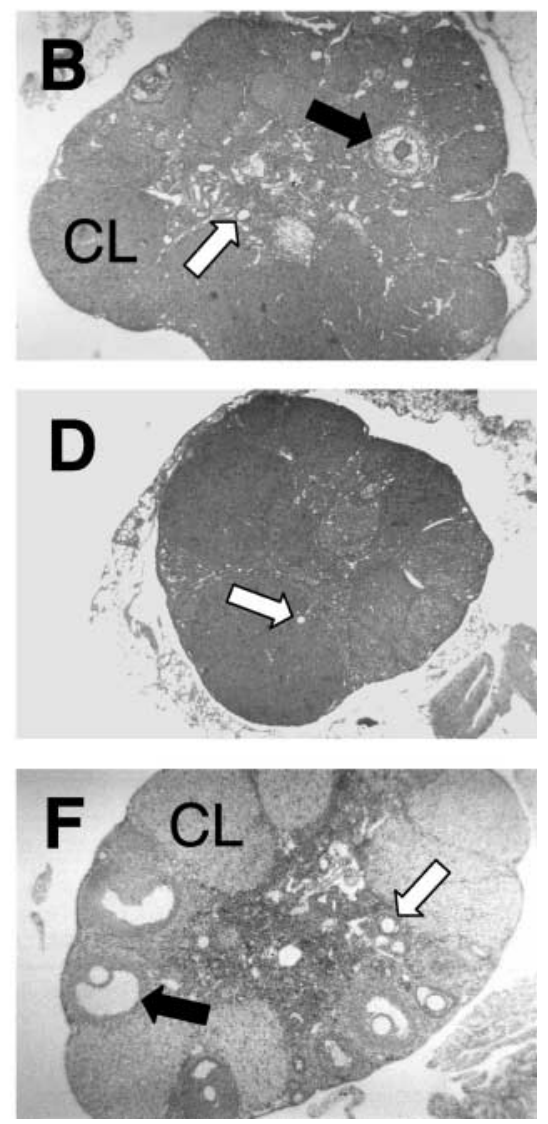

Figure 5 Ovarian sections of mice immunized with polyepitope AgZ or ZP1 peptide. Female BALB/c or CBA mice were immunized in Freund's adjuvants and boosted three times at 2-week intervals with AgZ fused to maltose-binding protein or ZP1 fused to a $6 \mathrm{XH}$ is tag. Fertility of mice was determined by mating 3 weeks prior to collection of ovaries. Ovaries are from PBS-treated fertile (A) and infertile (B) or AgZ-treated fertile (C) and infertile (D) CBA mice, 8 weeks after the final boost, or from ZP1-treated fertile (E) or infertile (F) BALB/c mice, 5 weeks after the final boost. CL, corpora luteum. Solid arrows indicate antral follicles; open arrows indicate preantral follicles. 
response to immunization with conjugated peptides, although there was considerable variation in the levels between individual mice. Peptide-specific IgG antibody levels in mice immunized with SP56 + GMCSF + PRL were $2-10$-fold less than in mice immunized with single peptides, indicating that suppression of epitope-specific antibodies occurred when mice were immunized with multiple peptides in conjugated form. The most consistent antibody responses were to the two peptides derived from zona pellucida proteins (ZP1 and ZP3). As the ZP1 and ZP3 proteins are not expressed until follicles commence development around birth (Millar et al. 1993, Epifano et al. 1995), self-reactive T helper cells may not be deleted for zona pellucida peptides as for other self-proteins (MacLennan 1995), enabling more consistent induction of antibody responses. Nevertheless, there was no absolute link between antibody levels and infertility with any of the peptide antigens, and this is comparable to results reported elsewhere (Lea et al. 1998). This suggests that other factors, such as T-cell responses or antibody avidity and isotype, in combination with antibody levels, are responsible for the immunocontraceptive effects we observed.

Polyepitope antigens (AgA and $\mathrm{AgB}$ ) containing mousespecific peptides have previously been shown to reduce fertility in mice (Hardy et al. 2002a). In the present study, we have shown that the antibody responses were preferentially directed against epitopes in the longer peptide sequences. These longer peptides (SP56 and ZP1) are more likely to contain multiple antigen-specific $T$ - and B-cell epitopes, and this could explain the production of antibodies preferentially against them in the polyepitopes. This result demonstrates the potential disadvantage of adopting a peptide approach to contraceptive vaccine design, since immunodominance of epitopes can occur by selective and dominant activation of peptide-specific B cells (Ju et al. 1993).

Previously it has been shown that BALB/c mice immunized with synthetic peptides containing multiple ZP3 epitopes elicit higher ZP3-specific antibodies and show greater infertility than those immunized with single peptides (Sadler et al. 1999). Therefore, a polyepitope antigen (AgZ) was produced that contained three tandem repeats of a ZP3 B-cell epitope to test whether repeated epitopes could overcome the observed lack of antibody responses to ZP3 in mice immunized with AgA and AgB. The ZP1 peptide was included in $\mathrm{AgZ}$ as it was previously reported to have contraceptive effect (Hardy et al. 2002a) and consistently induced antibodies. Indeed, BALB/c mice immunized with AgZ produced both ZP1 and ZP3 antibodies, although there was considerable variation in the ZP3 antibody levels (over 100-fold difference) between individual mice. Comparable variation (30-fold differences between individual mice) was reported in mice after immunization with the synthetic ZP3 peptides (Sadler et al. 1999). Importantly, BALB/c mice immunized with $\mathrm{AgZ}$ and $\mathrm{AgB}$ produced similar levels of ZP1 antibodies, demonstrating that recombinant proteins encoding repeated epitopes are able to elicit antibody responses while not affecting responses to adjacent peptides. In contrast, CBA mice immunized with AgZ showed lower levels of ZP1-specific antibodies than BALB/C mice, and did not produce detectable ZP3-specific antibodies. Levels of antibodies induced in response to immunization with repeated ZP3 B-cell epitopes are therefore dependent on mouse strain, as has been reported elsewhere for polyepitopes comprising multiple peptides (Chai et al. 1992).

Although the proportion of BALB/C mice immunized with AgZ that produced litters (78\%) was not significantly different from controls $(80 \%)$, there was a highly significant reduction in the mean litter sizes in the fertile mice, and this correlated with the levels of ZP3-specific antibodies. The only two infertile mice had the highest antibody levels, and two mice with intermediate antibody levels each had only one pup. There was no evidence of pathologic effects on the ovaries of BALB/C mice immunized with AgZ, despite the inclusion of a ZP3 T-cell epitope (NSSSSQFQ) that induces oophoritis (ovarian inflammation) in some mouse strains (Rhim et al. 1992). The interference in fertility in BALB/C mice is therefore probably due to prevention of fertilization or implantation by ZP3-specific antibodies. By contrast, 50\% of CBA mice immunized with AgZ lacked developing follicles and were infertile without any evidence for the presence of ZP3-specific antibodies. This rate of ovarian pathology is comparable to the reported incidence of oophoritis in CBA mice exposed to the NSSSSQFQ epitope (Lou et al. 1995), although mice that develop oophoritis after passive immunization with ZP3 peptide-induced T cells are fertile (Bagavant et al. 1999). Our results do, however, suggest that an alternative to antibody-mediated infertility occurs in CBA mice, perhaps through T cell-mediated destruction of developing follicles.

The apparent association of ZP1 and ZP3 antibodies with contraceptive effects in some mice immunized with recombinant polyepitopes, but not with the conjugated peptides, may reflect the manner in which antigens were prepared. Polyepitopes were expressed as soluble proteins in E. coli, and this may have provided conformational B-cell epitopes that were absent from the peptides. Alternatively, novel epitopes for the ZP1 or the adjacent ZP3 peptides may have been created at junction sites in the polyepitopes, as has been reported in other studies (Dalum et al. 1996, Partidos \& Kanse 1997). However, we did not test whether such novel or conformational epitopes for ZP1 or ZP3 were created in the polyepitopes in the present study.

On the basis of our results, we suggest that improvements to species-specific contraceptive peptide vaccines can be addressed in several ways. Firstly, contraceptive antibody responses to immunization with polyepitopes could be improved through the use of repeated epitopes. Increasing copy number has been shown to correlate with corresponding increases in contraceptive antibody levels 
both by our studies and by others. The number (Marussig et al. 1997, Oscherwitz et al. 1999), orientation (Partidos et al. 1992) and use of immune enhancers such as cytokines (Ramsay \& Ramshaw 1997) can be applied to improve the immunogenicity of subdominant epitopes. Secondly, the main criteria for selecting peptides in this study were to test combinations of peptides from key proteins for a broad a range of physiological targets. Polyepitope vaccines that simultaneously target species-specific regions of multiple proteins with similar structural or functional importance, such as all three zona pellucida proteins ZP1, 2 and 3, might induce more effective contraception. This approach is supported by our demonstration that contraceptive effectiveness is increased when the ZP1 and ZP3 are used in combination and that contraceptive mouse-specific ZP2 peptides are likely to exist (Hinsch et al. 1998, Sun et al. 1999). Thirdly, nonantibody immune responses, such as cytotoxic T-cell lymphocytes (CTLs), may generate immunocontraceptive effects and contraception after immunization with the ZP3 peptide has been reported to require both T-cell and antibody responses (Lou \& Borillo 2003). The identification of T-cell epitopes able to induce CTLs for appropriate reproductive targets and their incorporation into polyepitopes is likely therefore to improve immunogenicity, in a similar manner to those included in anticancer polyepitope vaccines now under development (Suhrbier 2002). Finally, replicating virus vaccines expressing the entire mouse ZP3 protein (Jackson et al. 1998, Lloyd et al. 2003) appear considerably more effective at inducing infertility than when ZP3 protein alone is used to immunize mice (Hardy et al. 2003). Therefore, delivery of polyepitope antigens using recombinant virus delivery systems could be expected to improve contraceptive effects.

\section{Acknowledgements}

The authors would like to acknowledge the technical assistance of Julia Ellyard, Jenny Pekin, Juliet Fisher and Kelly Debono. The authors are grateful to Charles Krebs and Warren Muller for statistical advice and analyses. This work was supported by funds provided by the Australian Grains Research and Development Corporation (CSV16) and the Australian Government's Cooperative Research Centres Program.

\section{References}

Aitken RJ 2002 Immunocontraceptive vaccines for human use. Journal of Reproductive Immunology 57 273-287.

Bach JF, Koutouzov S \& van Endert PM 1998 Are there unique autoantigens triggering autoimmune diseases? Immunological Reviews 164 139-155.

Bagavant H, Adams S, Terranova P, Chang A, Kraemer FW, Lou Y, Kasai K, Luo AM \& Tung KS 1999 Autoimmune ovarian inflammation triggered by proinflammatory (Th1) $\mathrm{T}$ cells is compatible with normal ovarian function in mice. Biology of Reproduction $\mathbf{6 1}$ 635-642.

Bandivdekar AH, Koide SS \& Sheth AR 1991 Antifertility effects of human sperm antigen in female rats. Contraception 44 559-569.
Barber MR \& Fayrer-Hosken RA 2000 Possible mechanisms of mammalian immunocontraception. Journal of Reproductive Immunology 46 103-124.

Boeckmann B, Bairoch A, Apweiler R, Blatter MC, Estreicher A, Gasteiger E, Martin MJ, Michoud K, O'Donovan C, Phan I, Pilbout S \& Schneider M 2003 The SWISS-PROT protein knowledge base and its supplement TrEMBL in 2003. Nucleic Acids Research 31 $365-370$.

Bradley MP, Eade J, Penhale J \& Bird P 1999 Vaccines for fertility regulation of wild and domestic species. Journal of Biotechnology 73 91-101.

Carino C, Prasad S, Skinner S, Dunbar B, Chirinos M, Schwoebel E \& Larrea F 2002 Localization of species conserved zona pellucida antigens in mammalian ovaries. Reproductive Biomedicine Online $4116-126$

Chai SK, Clavijo P, Tam JP \& Zavala F 1992 Immunogenic properties of multiple antigen peptide systems containing defined $\mathrm{T}$ and $\mathrm{B}$ epitopes. Journal of Immunology 149 2385-2390.

Chen JS, Lorenz RG, Goldberg J \& Allen PM 1991 Identification and characterization of a T cell-inducing epitope of bovine ribonuclease that can be restricted by multiple class II molecules. Journal of Immunology 147 3672-3678.

Coligan JE, Kruisbeek AM, Marguiles DH, Shevach EM \& Strober W 1995 Current Protocols in Immunology. New York: Wiley.

Dalum I, Jensen MR, Hindersson P, Elsner HI \& Mouritsen S 1996 Breaking of B cell tolerance toward a highly conserved self protein. Journal of Immunology 157 4796-4804.

Delves PJ, Lund T \& Roitt IM 2002 Antifertility vaccines. Trends in Immunology 23 213-219.

Epifano O, Liang LF, Familari M, Moos MC Jr \& Dean J 1995 Coordinate expression of the three zona pellucida genes during mouse oogenesis. Development 121 1947-1956.

Ferro VA 2002 Current advances in antifertility vaccines for fertility control and noncontraceptive applications. Expert Reviews of Vaccines 1 443-452.

Gasteiger E, Gattiker A, Hoogland C, Ivanyi I, Appel RD \& Bairoch A 2003 ExPASy: the proteomics server for in-depth protein knowledge and analysis. Nucleic Acids Research 31 3784-3788.

Grandy JW \& Rutberg AT 2002 An animal welfare view of wildlife contraception. Reproduction $601-7$.

Hall LL, Yurewicz EC, Sacco AG \& Moghissi KS 1995 Generation and characterization of antibodies against synthetic peptides of porcine zona pellucida ZP3 alpha. Journal of the Society for Gynecologic Investigation 2 552-558.

Hardy CM \& Holland MK 1996 Cloning and expression of recombinant rabbit fertilin. Molecular Reproduction and Development $\mathbf{4 5}$ 107-116.

Hardy CM, Pekin J \& ten Have J 2002a Mouse-specific immunocontraceptive polyepitope vaccines. Reproduction Supplement $\mathbf{6 0}$ 19-30.

Hardy CM, ten Have JF, Mobbs KJ \& Hinds LA 2002b Assessment of the immunocontraceptive effect of a zona pellucida 3 peptide antigen in wild mice. Reproduction Fertility and Development 14 $151-155$.

Hardy CM, ten Have JF, Pekin J, Beaton S, Jackson RJ \& Clydesdale G 2003 Contraceptive responses of mice immunized with purified recombinant mouse zona pellucida subunit 3 (mZP3) proteins. Reproduction 126 49-59.

Hinsch E, Hagele W, Bohle RM, Schill WB \& Hinsch KD 1998 Evaluation of ZP2 domains of functional importance with antisera against synthetic ZP2 peptides. Journal of Reproduction and Fertility $114245-251$.

Hinsch E, Oehninger S, Schill WB \& Hinsch KD 1999 Species specificity of human and murine anti-ZP3 synthetic peptide antisera and use of the antibodies for localization and identification of ZP3 or ZPC domains of functional significance. Human Reproduction $\mathbf{1 4}$ 419-428.

Hoskinson RM, Rigby RD, Mattner PE, Huynh VL, D'Occhio $M$, Neish A, Trigg TE, Moss BA, Lindsey MJ \& Coleman GD et al. 
1990 Vaxstrate: an anti-reproductive vaccine for cattle. Australian Journal of Biotechnology 4 166-170, 176.

Hughes DC \& Barratt CL 1999 Identification of the true human orthologue of the mouse Zp1 gene: evidence for greater complexity in the mammalian zona pellucida? Biochimica et Biophysica Acta $1447303-306$.

Jackson RJ, Maguire DJ, Hinds LA \& Ramshaw IA 1998 Infertility in mice induced by a recombinant ectromelia virus expressing mouse zona pellucida glycoprotein 3. Biology of Reproduction $\mathbf{5 8}$ $152-159$.

Ju ST, Nonogaki T, Bernatowicz MS \& Matsueda GR 1993 The B cell immune response to an idiotype-inducing peptide epitope can be inhibited by immunodominance of a neighboring epitope. Journal of Immunology 1502641 -2647.

Lea IA, van Lierop MJ, Widgren EE, Grootenhuis A, Wen Y, van Duin M \& O'Rand MG 1998 A chimeric sperm peptide induces antibodies and strain-specific reversible infertility in mice. Biology of Reproduction 59 527-536.

Lloyd ML, Shellam GR, Papadimitriou JM \& Lawson MA 2003 Immunocontraception is induced in BALB/c mice inoculated with murine cytomegalovirus expressing mouse zona pellucida 3. Biology of Reproduction 68 2024-2032.

Lou Y, Ang J, Thai H, McElveen F \& Tung KS 1995 A zona pellucida 3 peptide vaccine induces antibodies and reversible infertility without ovarian pathology. Journal of Immunology 155 2715-2720.

Lou YH \& Borillo J 2003 Migration of T cells from nearby inflammatory foci into antibody bound tissue: a relay of $\mathrm{T}$ cell and antibody actions in targeting native autoantigen. Journal of Autoimmunity 21 27-35.

MacLennan IC 1995 Autoimmunity. Deletion of autoreactive B cells. Current Biology 5 103-106.

Marussig M, Renia L, Motard A, Miltgen F, Petour P, Chauhan V, Corradin G \& Mazier D 1997 Linear and multiple antigen peptides containing defined $\mathrm{T}$ and $\mathrm{B}$ epitopes of the Plasmodium yoelii circumsporozoite protein: antibody-mediated protection and boosting by sporozoite infection. International Immunology $\mathbf{9}$ 1817-1824.

Millar SE, Chamow SM, Baur AW, Oliver C, Robey F \& Dean J 1989 Vaccination with a synthetic zona pellucida peptide produces long-term contraception in female mice. Science 246 935-938.

Millar SE, Lader ES \& Dean J 1993 ZAP-1 DNA binding activity is first detected at the onset of zona pellucida gene expression in embryonic mouse oocytes. Developmental Biology 158 410-413.

Muller S 1988 Peptide-carrier conjugation. In Synthetic Polypeptides as Antigens, pp 95-130. Eds MHV Van Regenmortel, JP Briand, $S$ Muller \& S Plaue. Amsterdam: Elsevier.

Naz RK 2000 Fertilization-related sperm antigens and their immunocontraceptive potentials. American Journal of Reproductive Immunology 44 41-46.

Nettles VF 1997 Potential consequences and problems with wildlife contraceptives. Reproduction Fertility and Development $\mathbf{9}$ 137-143.

O'Hern PA, Bambra CS, Isahakia M \& Goldberg E 1995 Reversible contraception in female baboons immunized with a synthetic epitope of sperm-specific lactate dehydrogenase. Biology of Reproduction 52 331-339.
Oscherwitz J, Zeigler ME, Gribbin TE \& Cease KB 1999 A V3 loop haptenic peptide sequence, when tandemly repeated, enhances immunogenicity by facilitating helper T-cell responses to a covalently linked carrier protein. Vaccine 17 2392-2399.

Partidos C, Stanley C \& Steward M 1992 The effect of orientation of epitopes on the immunogenicity of chimeric synthetic peptides representing measles virus protein sequences. Molecular Immunology 29 651-658.

Partidos CD \& Kanse C 1997 Specificity of the T-cell responses in covalently linked peptides each comprising of a T helper epitope. Molecular Immunology 34 1105-1111.

Ramsay AJ \& Ramshaw IA 1997 Cytokine enhancement of immune responses important for immunocontraception. Reproduction Fertility and Development 9 91-97.

Rhim SH, Millar SE, Robey F, Luo AM, Lou YH, Yule T, Allen P, Dean J \& Tung KS 1992 Autoimmune disease of the ovary induced by a ZP3 peptide from the mouse zona pellucida. Journal of Clinical Investigation 89 28-35.

Sadler K, Bird PH, Brown LE \& Jackson DC 1999 The antigenic and immunogenic properties of synthetic peptide immunocontraceptive vaccine candidates based on gamete antigens. Vaccine $\mathbf{1 8}$ $416-425$.

Smith SG 1999 The polyepitope approach to DNA vaccination. Current Opinions in Molecular Therapeutics 1 10-15.

Subramanian S, Andal S, Karande AA \& Radhakantha Adiga P 2003 Epitope mapping and evaluation of specificity of T-helper sites in four major antigenic peptides of chicken riboflavin carrier protein in outbred rats. Biochemical and Biophysical Research Communications 311 11-16.

Suhrbier A 2002 Polytope vaccines for the codelivery of multiple CD8 T-cell epitopes. Expert Reviews of Vaccines $1207-213$.

Sun W, Lou YH, Dean J \& Tung KS 1999 A contraceptive peptide vaccine targeting sulfated glycoprotein ZP2 of the mouse zona pellucida. Biology of Reproduction 60 900-907.

Talwar GP 1997 Fertility regulating and immunotherapeutic vaccines reaching human trials stage. Human Reproduction Update 3 301-310.

Tyndale-Biscoe CH 1994 Virus-vectored immunocontraception of feral mammals. Reproduction Fertility and Development 6 $281-287$.

Valmori D, Dutoit V, Ayyoub M, Rimoldi D, Guillaume P, Lienard D, Lejeune F, Cerottini JC, Romero P \& Speiser DE 2003 Simultaneous $\mathrm{CD}^{+} \mathrm{T}$ cell responses to multiple tumor antigen epitopes in a multipeptide melanoma vaccine. Cancer Immunology $\mathbf{3} 15$.

Zhu X \& Naz RK 1994 Sequence homology among sperm antigens involved in mammalian fertilization: search for a common epitope for immunocontraception. Archives of Andrology 33 141-144.

Zhu X \& Naz RK 1999 Comparison of ZP3 protein sequences among vertebrate species: to obtain a consensus sequence for immunocontraception. Frontiers of Biosciences 4 D212-D215.

Received 14 April 2004

First decision 14 June 2004

Accepted 28 June 2004 